\title{
Corrigendum: Exploring the learnings derived from catalytic experiences in a leadership context
}

\author{
Authors: \\ Daphna S. Horowitz ${ }^{1}$ \\ René van Eeden ${ }^{2}$ \\ Affiliations: \\ ${ }^{1}$ Department of Industrial \\ Psychology and People \\ Management, University of \\ Johannesburg, South Africa \\ ${ }^{2}$ Department of Psychology, \\ University of South Africa, \\ South Africa \\ Correspondence to: \\ Daphna Horowitz \\ Email: \\ daphna@peacsolutions.co.za \\ Postal address: \\ 11 Study Rd, Glenhazel, \\ Johannesburg 2192, \\ South Africa \\ Dates: \\ Published: 09 Dec. 2015 \\ How to cite this article: \\ Horowitz, D.S., \& Van \\ Eeden, R. (2015). \\ Corrigendum: Exploring \\ the learnings derived from \\ catalytic experiences in \\ a leadership context. $S A$ \\ Journal of Human Resource \\ Management/SA Tydskrif vir \\ Menslikehulpbronbestuur, \\ 13(1), Art. \#598, 1 page. \\ http://dx.doi.org/10.4102/ \\ sajhrm.v13i1.598-1 \\ Note: \\ Doi of original article: http:// \\ dx.doi.org/10.4102/sajhrm. \\ v13i1.598

\section{Copyright:} \\ (C) 2015. The Authors. \\ Licensee: AOSIS \\ OpenJournals. This work is \\ licensed under the Creative \\ Commons Attribution \\ License.

\section{Read online:}

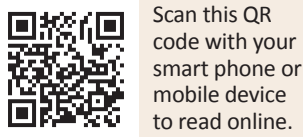

This article is based on a master's dissertation completed by the first author in partial fulfilment of the requirements for the degree Masters in Philosophy, Personal and Professional Leadership at the University of Johannesburg. The authors requested a change in terms of the author details originally published to now reflect the affiliation with said university.

The Affiliation section has been updated to reflect the correct first affiliation. 